\title{
Relationship between root growth potential and field performance in Aleppo pine
}

\author{
Antonio D. Del CAMPo ${ }^{a *}$, Rafael M. NAVARRo-CERRILlo ${ }^{\mathrm{b}}$, Javier HERMOSO $^{\mathrm{c}}$, Antonio J. IBÁÑNE $^{\mathrm{a}}$ \\ a Departamento de Ingeniería Hidráulica y Medio Ambiente, Universidad Politécnica Valencia, Camí de Vera s/n, 46022 Valencia, Spain

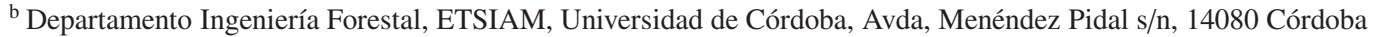 \\ ${ }^{\mathrm{c}}$ Conselleria de Territori y Habitatge, Generalitat Valenciana, c/ Gregorio Gea, 27, Valencia, Spain
}

(Received 14 September 2006; accepted 20 December 2006)

\begin{abstract}
Commercial stocks of Aleppo pine in Spain vary in quality, but there is no accepted standard for evaluating quality. A RGP test was applied to six commercial seedling stocklots at two dates (November, February) and under two test conditions (growth-chamber, greenhouse). The RGP's predictive ability was evaluated on two contrasting sites. There was a considerable variation in the RGP depending on application date, test conditions and stock factors. The RGP results for November were correlated with each other but they did not explain outplanting performance. The February results in the growth-chamber correlated well with survival at both sites. Regression models explained survival both in the lower $\left(R^{2}=97 \%\right)$ and in the higher $\left(R^{2}=92 \%\right)$ quality sites. RGP has a valid predictive ability for this species although it is sensitive to the test conditions. In this sense, a shorter and more intensive test performed right before planting may be more reliable.
\end{abstract}

outplanting / seedling quality / site quality / prediction model

Résumé - Relation entre potentiel de croissance racinaire et performance du pin d'Alep en plantation. Les productions commerciales de plants de pin d'Alep en Espagne présentent une importante variabilité de qualité, mais aucun test standardisé d'évaluation de la qualité des plants n'a été élaboré. Un test de potentiel de croissance racinaire a été conduit sur des plants de six lots commerciaux de pin d'Alep à deux dates (novembre et février) et dans deux conditions de test différentes (chambre de croissance et serre) Le potentiel de croissance racinaire (RGP) a été évalué sur deux sites écologiquement contrastés. RGP a fortement varié avec la date, les sites de plantation et les lots de plants. Les évaluations de RGP étaient corrélées entre elles en novembre, sans expliquer les taux de réussite en plantation. Les valeurs de RGP évaluées en février en chambre de croissance ont présenté de bonnes corrélations avec la survie des plants dans les deux sites. Les modèles de régression ont expliqué la survie des plants à la fois dans le site faiblement productif $\left(R^{2}=97 \%\right)$ et dans le site productif $\left(R^{2}=92 \%\right)$. RGP présente un fort potentiel prédictif cette espèce bien qu'il soit sensible aux conditions de test. Dans ce sens, un test plus court et plus intensif réalisé bien avant la plantation peut être plus fiable.

plantation / qualité des plants / qualité du site / modèle prédictif

\section{INTRODUCTION}

Aleppo pine is the species most used in eastern Spain (Valencia region) for reforestation programmes. Its important values are associated with landscape quality, soil protection and hydrological cycle stabilization. During the last 30 years, destructive wildfires have considerably affected their natural stands [17], which have prompted an increase in public reforestation efforts in those areas where natural regeneration has not been successful. However, the harshness of the Mediterranean climate frequently leads to high mortality rates in these programmes, with mean percentages of around 35\% [1]. This has usually been attributed, in addition to other factors, to poor stock quality $[19,28]$. This stock is produced in nurseries using different growing regimes, resulting in stock heterogeneity [27].

Root growth potential (RGP) is considered to be one of the most reliable tests in assessing planting stock quality

* Corresponding author: ancamga@dihma.upv.es and vigour $[25,29]$ and has been the subject of several reviews $[5,24,30]$. According to Burdett [5], the relationship between field performance and RGP is so well confirmed that the lack of response in some studies may be attributed to uncontrolled experimental factors (e.g. site, planting date or stock range of variation). Recently, the empirical evidence of the test has been supported by process-based models for a wide range of environmental conditions [11]. However, the RGP results should be interpreted cautiously when using them as an indicator of seedling performance potential $[9,24]$. One of the test's main drawbacks is the sensitivity of the root system to cold soils during the planting season [30]. Therefore, these and other authors [5] agree that the validity of the RGP as a measurement of seedling vigour is largely a function of site conditions, with its predictive ability increasing as the site becomes harsher. In this sense, the RGP or seedling quality attributes in general might be considered good indicators of a relative performance potential $[5,21]$.

In Mediterranean Spain, the exceptionally harsh site conditions increase the need for the production of the highest quality 
stock possible. To this end, the effects of seedling quality on the field performance of Aleppo pine have been examined in several studies $[16,19,28]$. However, in spite of this work, there is no uniformity in the morphological and physiological attributes that promote a successful establishment [6], nor did the RGP really predict field performance in all the studies. In some of the latter, a significant correlation between RGP and survival was found $[16,34]$, but in others this was not so $[15,27]$. The lack of uniformity in the environmental conditions for the RGP test may be the main reason for these discrepancies (e.g. culture and environmental conditions or time intervals) $[11,25]$.

These imprecise results have not yet permitted the implementation of effective operational stock-quality testing programmes. In some cases, in order to comply with administrative regulations, nursery managers carry out stock quality assessments that may not be reliable predictors of field performance potential. These are usually made at the beginning of the planting season, in October, and are expected to be valid thereafter for the five-month long planting season. Therefore, it may be necessary to evaluate the potential predictive ability of the RGP test for this species and to identify the test conditions which best anticipate field performance.

Thus, the objective of this study was to evaluate the factors that influence RGP in Pinus halepensis and assess its usefulness as a stock quality attribute. Specifically, (i) the effect of lift date, test conditions and stocklot on RGP; (ii) the influence of other seedling quality attributes on the expression of the RGP; and (iii) to examine the relationship between RGP and field performance on two contrasting sites.

\section{MATERIALS AND METHODS}

\subsection{Plant material and seedling quality}

A total of six seedling stocklots of Aleppo pine (Pinus halepensis Mill.) grown in commercial nurseries during the 2004 season were used (Tab. II). Each nursery had a particular growing regime for this species, although in all cases the stock was $1+0$ (sown between March and May), cultivated in the open air, in a peat or peat-coconut fibre mix in $200 \mathrm{~cm}^{3}$ per seedling containers, and the fertilization regime differed among nurseries. $\mathrm{Ca}$ and $\mathrm{Hu}$ stocklots were fertilized by adding slow- release fertilizer (Plantacote-Pluss ${ }^{\odot}$ 14-8-15) to the growing media at a dose of $3 \mathrm{~kg} \mathrm{~m}^{-3}$. The remaining stocklots were fertigated with N-P-K concentrations ( $\mathrm{mg} \mathrm{L}^{-1}$, during the growth phase) of 73-51-88 for Ge, 105-19-56 for $\mathrm{Cl}, 127-18-32$ for $\mathrm{Fa}$ and 120-11-54 for $\mathrm{Ht}$. All the stocklots belonged to the Eastern inland provenance (zone $10,39^{\circ} 03^{\prime} \mathrm{N}, 01^{\circ} 05^{\prime} \mathrm{W}, 640-900 \mathrm{~m}$ altitude). On October 20 (2004) and January 15 (2005), representative samples from each stocklot were lifted and held in the experimental nursery where the study was performed (Quart de Poblet, Valencia, $39^{\circ} 38^{\prime} \mathrm{N}, 0^{\circ} 22^{\prime} \mathrm{W}, 11 \mathrm{~m}$ a.s.l.) (Tab. I). On both dates, a randomly selected sample of seedlings was assessed for height, root collar diameter (RCD), root and shoot dry mass, nutrient concentration of the needles, shoot concentration of non-structural carbohydrates and root growth potential (RGP) following standard methods [23] (Tab. II). Total root length $(\mathrm{cm})$, root average diameter $(\mathrm{cm})$, number of root tips and pre-existing white roots (length, diameter and tips of white roots already present on the plug before the RGP) were measured using WinRhizo ${ }^{\odot}$ v.3.1 software (Regents Instruments Inc.) (Tab. II). For nutrient analyses, a composite sample of foliar tissue from 25 plants (identical weight from every seedling) per treatment was ovendried $\left(70{ }^{\circ} \mathrm{C}\right)$ and ground through a $0.5 \mathrm{~mm}$ screen. After plant tissue preparation by dry ash method, nitrogen was determined by the micro Kjeldahl method with a Kjeltec Auto 1030 Analyser (Tecator, Sweden) after digesting the samples in concentrated $\mathrm{H}_{2} \mathrm{SO}_{4}$ with a selenium catalyst; $P$ was assayed colorimetrically using the phosphomolybdovanadate method $(420 \mathrm{~nm})$ in a colorimeter (Technicon Autoanalyzer AAII); $K$ was determined using a Varian SpectraAA10 Atomic Absorption Spectrometer [2]. Starch and soluble sugars were determined in shoots by means of a controlled acid hydrolysis procedure [26].

\subsection{Root growth potential}

The RGP test was performed under two test conditions, a conventional greenhouse and a growth chamber (IBERCEX, Valencia, Spain) and at two different times: November 2004 and February 2005 (Tabs. I and III). These conditions were chosen because (a) they represent test conditions currently being used by foresters and are operationally feasible and (b) the planting season in Mediterranean Spain runs from mid October to March. The greenhouse tests, each lasting 31 days, started on October 28 and January 21. No artificial lighting or heating was provided, and the outside meteorological conditions were only slightly and indirectly modified by the influence of the greenhouse's polycarbonate roof (Tab. III). The growth chamber tests started on November 8 and February 4 and lasted 10 days. The environmental conditions used were close to those considered to be optimal by Burdett [4] (Tab. III). During the tests, temperature $\left({ }^{\circ} \mathrm{C}\right)$ and relative humidity (\%) were monitored daily for both conditions using Micro-Hobo ${ }^{\circledR}$ Weather Stations (Micro-HWS H21-002. Onset Computer Corporation, Bourne, MA, USA). Light intensity was measured daily at midday $(\mathrm{UTC}+1)$ using a digital Lux Meter (FT-710, FAITHFUL. Taipei, TW).

In each of the four tests, 15 seedlings per stocklot were potted in $50 \times 35 \times 40 \mathrm{~cm}(701)$ containers in a perlite \#2 growing medium. Each stocklot was represented by a row of five seedlings per replicate. The experiment layout was a randomized complete block design with three blocks (replications). Seedlings were watered during the experiments but no nutrients were provided. At the conclusion of the tests, the seedlings were carefully removed and the number of white roots (> $10 \mathrm{~mm})$ and the dry weight $\left(65^{\circ} \mathrm{C}, 24 \mathrm{~h}\right)$ of all the new roots that grew outside the plug into the perlite medium were determined [24].

\subsection{Outplanting performance}

In February 2005, the seedling stocklots were field planted at two locations with contrasting site characteristics. The better quality site (La Hunde, $39^{\circ} 05^{\prime} \mathrm{N} ; 1^{\circ} 12^{\prime} \mathrm{W}$; $940 \mathrm{~m}$ a.s.l.) was on a sandy clayloam xerochrept soil deeper than $60 \mathrm{~cm}$. The climate is Mediterranean continental with an average annual rainfall and temperature of $495 \mathrm{~mm}$ and $13.7^{\circ} \mathrm{C}$, respectively. The lower quality site (Enguera, $38^{\circ} 56^{\prime} \mathrm{N} ; 0^{\circ} 46^{\prime} \mathrm{W}$; $605 \mathrm{~m}$ a.s.l) was on a clay-loam xerorthent soil, shallow $(<30 \mathrm{~cm})$ and rocky. Climate is Mediterranean maritime (P: $495 \mathrm{~mm}$ and $\mathrm{T}: 12.8^{\circ} \mathrm{C}$ ). Both sites have alkaline $\mathrm{pH}(>7.9)$ and low organic matter content $(<2 \%)$. In each site, the six seedling 
Table I. Details of cultural treatments, RGP tests and the dates of outplanting and quality assessments completed.

\begin{tabular}{|c|c|c|c|c|c|c|c|c|c|c|c|c|}
\hline \multirow{2}{*}{$\begin{array}{l}\text { Year } \\
\text { Action }\end{array}$} & \multicolumn{10}{|c|}{2004} & \multicolumn{2}{|c|}{2005} \\
\hline & Mar. & Apr. & May & Jun. & Jul. & Aug. & Sept. & Oct. & Nov. & Dec. & Jan. & Feb. \\
\hline Nursery sown seeds & - & - & & & & & & & & & & \\
\hline Seedlings quality test & & & & & & & & 20th & & & 15 th & \\
\hline RGP Greenhouse test & & & & & & & & - & - & & - & - \\
\hline RGP Growth chamber test & & & & & & & & & - & & & - \\
\hline Field planting & & & & & & & & & & & & - \\
\hline
\end{tabular}

stocklots were planted following a randomized block design, with 3 blocks, each containing 30 seedlings per stocklot in a row plot $(n=90$ seedlings per stocklot and per site). Site preparation (removal of preexisting natural vegetation and $30 \times 30 \times 30 \mathrm{~cm}$ hole openings) and planting were done manually by the same planting team. The number of surviving plants per plot, height and diameter (at $0.5 \mathrm{~cm}$ above soil) were recorded at the time of planting as well as in July and November of 2005. The relative height and diameter growth rates (RGR) were calculated from these data. [18].

\subsection{Statistical analyses}

For each RGP date, a two-factor analysis of variance (test conditions and seedling stocklot) was performed, with 3 replicates, to detect differences in the RGP values (the test conditions and start date effects were confounded). Then, a two-way ANOVA (stocklot $\times$ block) was conducted for each of the four RGPs to determine if RGP differed significantly between stocklots. Comparisons of means were made using Tukey's test [22] at the 0.05 significance level. Variables were examined to ascertain that they were normally distributed and that the variances were homogeneous (Levene test). In general, power transformations were used to meet ANOVA requirements.

Relationships between stock quality attributes, RGP and outplanting performance (survival and growth) were investigated through a simple linear correlation using the Pearson correlation coefficient [32]. Multiple linear regression analyses [22] were performed to determine if the RGP and other seedling quality attributes could help to explain performance differences. The stepwise method was selected for fitting the model (criterion to select a variable: $F$ probability for including $<0.05 ; F$ probability for excluding $>0.10$ ). In the model, the residuals were examined for normality. Prior to analysis, mean survival data were transformed by taking the arcsin of the square root of the survival proportion. Data were analyzed with SPSS 12.0 [31].

\section{RESULTS}

\subsection{Root growth potential}

Root growth potential values indicated a great variability according to the factors examined: date, seedling stocklot and test conditions (Fig. 1 and Tab. IV). Both RGP variables, i.e. new root dry weight and number of new roots longer than $1 \mathrm{~cm}$, showed similar patterns so only the former will be described hereinafter. For both dates, test conditions and stocklot

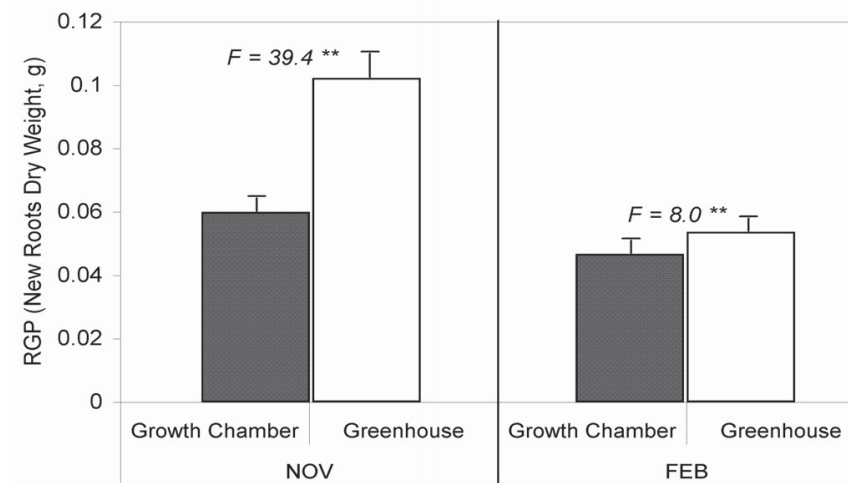

Figure 1. Root growth potential (RGP) for both test conditions (Greenhouse and Growth chamber) in November and February. For both dates, the $F$ statistic was significant at the $p<0.01$ level. Mean values and standard error.

factors had a significant effect on RGP (Fig. 1, ANOVAs not shown). Although both factors had a similar relative effect for the November lift date, the stocklot factor explained most of the variability ( $F=44.3$ compared to $F=8.0$ for test conditions) for plants lifted in February. For the latter, moreover, there was a significant interaction effect between the RGP test conditions and the seedling stocklot $(F=8.0)$, meaning that the RGP expression both in the growth chamber and in the greenhouse is dependent on the stocklot (i.e. on its morphology and physiology) (Tab. IV). Despite these differences, the RGP results from the chamber were significantly correlated with those from the greenhouse for plants lifted in November (0.996), whereas there was no significant relationship for those lifted in February. The mean RGP under the greenhouse conditions was higher than in the growth chamber for both dates (Fig. 1). While all stocklots performed better in the greenhouse than in the chamber in the November test, this was not always the case for the February test (Tab. IV).

Correlations between seedling quality attributes and RGP values were significant (a) in November tests, for the number of pre-existing white roots (length and tips number), and (b) in February tests, for the ratio Root length: Root tip (growth chamber test), and the root average diameter (greenhouse test). 
Table II. Mean values of morphological and physiological seedling attributes for the six stocklots tested in October and January.

\begin{tabular}{|c|c|c|c|c|c|c|c|c|c|c|c|c|c|c|}
\hline $\begin{array}{l}\text { Nursery } \\
\text { (seedling } \\
\text { stocklot) }\end{array}$ & $\begin{array}{l}\text { Height, } \\
\mathrm{H}(\mathrm{cm})\end{array}$ & $\begin{array}{l}\text { Diameter, } \\
\mathrm{D}(\mathrm{mm})\end{array}$ & $\begin{array}{l}\text { Shoot dry } \\
\text { Weight, S } \\
\text { (g) }\end{array}$ & $\begin{array}{l}\text { Root dry } \\
\text { weight, R } \\
\text { (g) }\end{array}$ & $\begin{array}{l}\text { Root } \\
\text { average } \\
\text { diameter } \\
(\mathrm{mm})\end{array}$ & $\begin{array}{l}\text { Root } \\
\text { length }(\mathrm{cm}) / \\
\text { Root tips }\end{array}$ & $\begin{array}{l}\text { White } \\
\text { roots } \\
\text { length } \\
(\mathrm{cm})\end{array}$ & $\begin{array}{l}\text { White } \\
\text { roots } \\
\text { average } \\
\text { diameter } \\
(\mathrm{mm})\end{array}$ & $\begin{array}{l}\text { White } \\
\text { roots } \\
\text { tips (\#) }\end{array}$ & $\begin{array}{l}\mathrm{N} \\
\left(\mathrm{mg} \mathrm{g}^{-1}\right)\end{array}$ & $\begin{array}{l}\mathrm{P} \\
\left(\mathrm{mg} \mathrm{g}^{-1}\right)\end{array}$ & $\begin{array}{l}\mathrm{K} \\
\left(\mathrm{mg} \mathrm{g}^{-1}\right)\end{array}$ & $\begin{array}{l}\text { Starch } \\
\left(\mathrm{mg} \mathrm{g}^{-1}\right)\end{array}$ & $\begin{array}{l}\text { Soluble } \\
\text { sugars } \\
\left(\mathrm{mg} \mathrm{g}^{-1}\right)\end{array}$ \\
\hline$n$ & 150 & 150 & 25 & 25 & 5 & 5 & 5 & 5 & 5 & $25^{\mathrm{a}}$ & $25^{\mathrm{a}}$ & $25^{\mathrm{a}}$ & $25^{\mathrm{a}}$ & $25^{\mathrm{a}}$ \\
\hline \multicolumn{15}{|l|}{ October } \\
\hline GE & 19.01 & 2.61 & 1.60 & 0.95 & 0.75 & 1.22 & 246 & 0.519 & 212 & 15.3 & 2.6 & 8.9 & 128 & 42 \\
\hline FA & 12.73 & 2.32 & 1.41 & 1.10 & 0.82 & 1.08 & 286 & 0.469 & 324 & 24.1 & 3.3 & 9.2 & 117 & 30 \\
\hline CL & 9.65 & 1.81 & 0.83 & 0.61 & 0.66 & 1.08 & 108 & 0.447 & 153 & 22.3 & 1.8 & 6.2 & 111 & 44 \\
\hline $\mathrm{HU}$ & 12.73 & 2.15 & 0.88 & 0.79 & 0.73 & 0.98 & 111 & 0.472 & 175 & 13.6 & 2.7 & 7.1 & 126 & 45 \\
\hline HT & 10.78 & 2.15 & 0.93 & 0.62 & 0.63 & 0.95 & 77 & 0.542 & 139 & 15.4 & 4.5 & 9.6 & 138 & 51 \\
\hline $\mathrm{CA}$ & 8.89 & 2.18 & 1.05 & 0.74 & 0.72 & 0.89 & 146 & 0.476 & 310 & 17.6 & 3.0 & 9.6 & 116 & 73 \\
\hline \multicolumn{15}{|l|}{ January } \\
\hline GE & 20.74 & 2.96 & 2.17 & 1.32 & 0.57 & 0.82 & 228 & 0.469 & 481 & 15.9 & 2.9 & 7.8 & 121 & 69 \\
\hline FA & 13.06 & 2.86 & 1.70 & 1.28 & 0.71 & 0.79 & 268 & 0.476 & 520 & 17.8 & 3.1 & 8.6 & 113 & 81 \\
\hline CL & 9.67 & 2.11 & 0.99 & 0.70 & 0.51 & 0.66 & 86 & 0.462 & 168 & 15.4 & 2.2 & 6.5 & 118 & 73 \\
\hline HU & 12.77 & 2.24 & 1.35 & 1.07 & 0.64 & 0.85 & 117 & 0.520 & 236 & 14.4 & 2.6 & 8.0 & 109 & 92 \\
\hline HT & 10.31 & 2.19 & 1.02 & 0.77 & 0.53 & 0.78 & 95 & 0.493 & 204 & 12.4 & 4.5 & 9.8 & 112 & 67 \\
\hline CA & 8.73 & 2.11 & 1.02 & 0.78 & 0.60 & 0.70 & 105 & 0.542 & 246 & 16.7 & 2.8 & 8.2 & 123 & 76 \\
\hline
\end{tabular}

${ }^{\text {a }}$ Nutrient concentrations were evaluated in needles and starch and soluble sugars in the whole shoot. $N=25$ seedlings in a composite sample. 
Table III. Environmental conditions recorded in the four RGP tests performed. $T$, temperature; $R H$, relative humidity. For the temperature, numbers between brackets represent the data range (absolute maximum and minimum values). Mean values and standard error.

\begin{tabular}{lccccc}
\hline RGP conditions (duration) & $\mathrm{T} \min \left({ }^{\circ} \mathrm{C}\right)$ & $\mathrm{T} \max \left({ }^{\circ} \mathrm{C}\right)$ & $\mathrm{RH} \min (\%)$ & $\mathrm{RH}$ max $(\%)$ & $\mathrm{Radiation}(\mathrm{klux})$ \\
\hline Nov-Greenhouse $(10.28-11.29)$ & $12.4(15.6-7.9)$ & $22.2(23.6-20.5)$ & 39.4 & 87.7 & 15.9 \\
Nov-Growth Chamber $(11.8-11.18)$ & $23.5(24.2-23.0)$ & $26.2(27.8-25.5)$ & 60.7 & 84.1 & 83.1 \\
Feb-Greenhouse $(1.21-2.22)$ & $7.9(15.7-2.2)$ & $19.8(24.3-16.3)$ & 31.9 & 17.6 \\
Feb-Growth Chamber $(2.4-2.14)$ & $22.0(23.5-20.5)$ & $24.8(26.0-23.5)$ & 58.0 & 83.9 & 33.2 \\
\hline
\end{tabular}

Table IV. $F$-values and significance of analysis of variance and RGP values for each test according to the stocklot factor $(C A, C L, F A, G E$, $H T$ and $H U$ ). Mean values and standard error In the same column, stocklots followed by different letters indicate significant differences (Tukey test) at $p$-value $<0.05 \%$.

\begin{tabular}{lllll}
\hline RGP type & $\begin{array}{l}\text { Nov-Greenhouse } \\
1 \text { dry weight, g }\end{array}$ & $\begin{array}{l}\text { Nov-Growth chamber } \\
1 \text { dry weight, g }\end{array}$ & $\begin{array}{l}\text { Feb-Greenhouse } \\
1,2 \text { dry weight, g }\end{array}$ & $\begin{array}{l}\text { Feb-Growth chamber } \\
1 \text { dry weight, g }\end{array}$ \\
\hline F-value & $15.73^{* *}$ & $16.00^{* *}$ & $52.88^{* *}$ & $14.62^{* *}$ \\
\hline CL & $0.062(0.008) \mathrm{c}$ & $0.038(0.004) \mathrm{c}, \mathrm{d}$ & $0.000(0.000) \mathrm{d}$ & $0.004(0.002) \mathrm{c}$ \\
FA & $0.183(0.022) \mathrm{a}$ & $0.104(0.013) \mathrm{a}$ & $0.089(0.010) \mathrm{a}$ & $0.031(0.012) \mathrm{c}, \mathrm{b}$ \\
GE & $0.121(0.013) \mathrm{a}, \mathrm{b}$ & $0.074(0.007) \mathrm{a}, \mathrm{b}$ & $0.061(0.009) \mathrm{b}, \mathrm{c}$ & $0.071(0.014) \mathrm{a}$ \\
HT & $0.090(0.013) \mathrm{b}, \mathrm{c}$ & $0.053(0.005) \mathrm{b}, \mathrm{c}$ & $0.042(0.004) \mathrm{c}$ & $0.056(0.009) \mathrm{a}$ \\
HU & $0.052(0.007) \mathrm{c}$ & $0.028(0.004) \mathrm{d}$ & $0.076(0.011) \mathrm{b}, \mathrm{c}$ & $0.070(0.012) \mathrm{a}$ \\
CA & & & $0.073(0.011) \mathrm{b}, \mathrm{c}$ & $0.043(0.005) \mathrm{a}, \mathrm{b}$ \\
\hline
\end{tabular}

${ }^{1}$ Power transformation to achieve variance homogeneity; ${ }^{2}$ variance homogeneity not achieved.

** Significant at 0.001-0.01 level.

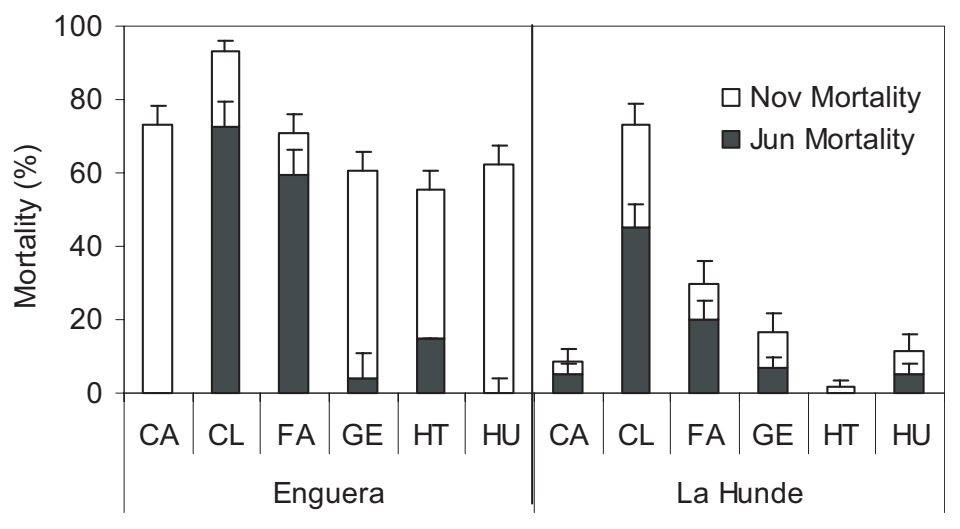

Field Site and Seedling Lot

Figure 2. Mean pre-summer (Jun) and post-summer (Nov) survival in Enguera and La Hunde sites of six outplanted Aleppo pine stocklots. Mean values and standard error.

\subsection{Field performance and relationship to RGP and seedling quality}

The performance of seedling stocklots in both locations differed between sites (Fig. 2). Pre-summer (June 05) and postsummer (November 05) average mortality at the better site (La Hunde) was 14 and 24\%, respectively, whereas in Enguera those values rose to 25 and $69 \%$ for each date, respectively. However, despite these differences, the ranking of the stocklots was similar at both sites. Thus, one of the stocklots (CL) exhibited the highest mortality rate both in Enguera
(93\%) and La Hunde (73\%), whereas HT had the lowest rate in both sites (56\% and 2\% in Enguera and La Hunde, respectively). The pre-summer weekly height growth rate was threefold greater than the post-summer one (from 0.011 to 0.003 week $^{-1}$ ), whereas the seedlings planted in La Hunde grew at an almost constant rate of about 0.005 week $^{-1}$ (data not shown). On the other hand, the diameter relative growth rate (not shown) showed similar pre-summer values for both sites (about 0.014 week $^{-1}$ ) and slightly lower summer values in the Enguera plot. The different stocklots showed a similar trend for growth as for mortality. 
Table V. Pearson correlations matrix between planting stock attributes (columns) and post summer field survival and growth (rows) for Engurea and La Hunde sites. Pearson's correlation index and level of significance $(n=6)$.

\begin{tabular}{|c|c|c|c|c|c|c|c|c|}
\hline & & $\begin{array}{l}\text { Height } \\
(\mathrm{cm})\end{array}$ & $\begin{array}{l}\text { Sturdiness } \\
\text { index, } \mathrm{cm} \\
\left(\mathrm{mm}^{-1}\right)\end{array}$ & 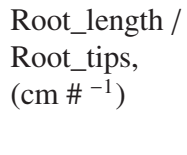 & $\begin{array}{l}\text { Pre-existing } \\
\text { white roots } \\
\text { average } \\
\text { diameter, }(\mathrm{cm})\end{array}$ & $\begin{array}{l}\text { Needle } \\
\left(\mathrm{K}, \mathrm{mg} \mathrm{g}^{-1}\right)\end{array}$ & $\begin{array}{l}\text { Shoot } \\
\text { starch, } \\
\left(\mathrm{mg} \mathrm{g}^{-1}\right)\end{array}$ & $\begin{array}{l}\text { RGP Growth } \\
\text { chamber dry } \\
\text { weight } \\
\text { (g DW-GC) }\end{array}$ \\
\hline \multirow[t]{6}{*}{$\begin{array}{l}\text { Oct Quality } \\
\text { / RGP-Nov }\end{array}$} & $\begin{array}{l}\text { Enguera-Relative } \\
\text { Diameter Growth }\end{array}$ & $\mathrm{ns}$ & ns & ns & ns & ns & $-0.848^{*}$ & ns \\
\hline & $\begin{array}{l}\text { Enguera-Relative } \\
\text { Height Growth }\end{array}$ & $-0.815^{*}$ & $-0.947^{* *}$ & $-0.861^{*}$ & $\mathrm{~ns}$ & ns & $\mathrm{ns}$ & ns \\
\hline & Enguera-SURVIVAL & ns & ns & ns & $0.820^{*}$ & ns & $0.892^{*}$ & ns \\
\hline & $\begin{array}{l}\text { Hunde-Relative } \\
\text { Diameter Growth }\end{array}$ & ns & ns & $-0.870^{*}$ & ns & ns & $\mathrm{ns}$ & ns \\
\hline & $\begin{array}{l}\text { Hunde-Relative } \\
\text { Height Growth }\end{array}$ & ns & $-0.870^{*}$ & $-0.863^{*}$ & ns & ns & ns & ns \\
\hline & Hunde- SURVIVAL & ns & ns & ns & ns & ns & ns & ns \\
\hline \multirow[t]{5}{*}{$\begin{array}{l}\text { Jan Quality } \\
\text { / RGP-Feb }\end{array}$} & $\begin{array}{l}\text { Enguera-Relative } \\
\text { Diameter Growth }\end{array}$ & ns & ns & ns & ns & $-0.859 a$ & ns & $-0.850^{*}$ \\
\hline & $\begin{array}{l}\text { Enguera-Relative } \\
\text { Height Growth }\end{array}$ & $-0.816^{*}$ & $-0.823^{*}$ & ns & ns & ns & $\mathrm{ns}$ & ns \\
\hline & Enguera-SURVIVAL & ns & ns & $0.814^{*}$ & $\mathrm{~ns}$ & ns & $\mathrm{ns}$ & $0.904^{*}$ \\
\hline & $\begin{array}{l}\text { Hunde-Relative } \\
\text { Diameter Growth }\end{array}$ & ns & ns & ns & $0.898^{*}$ & ns & ns & ns \\
\hline & Hunde-SURVIVAL & ns & ns & ns & ns & ns & ns & $0.835^{*}$ \\
\hline
\end{tabular}

ns: Not significant at 0.05 level; * significant at $0.01-0.05$ level; ${ }^{* *}$ significant at $0.001-0.01$ level.

Significant correlations between morphological seedling quality and field performance were found for attributes assessed after lifting in October or January (Tab. V), although only the seedling height was correlated in both data sets (negative correlation with height growth in Enguera). The average diameter of pre-existing white roots was positively correlated with growth (height and diameter), in both sites, and the ratio Root length: Root tip was correlated with final survival in Enguera. There was no significant correlation between greenhouse RGP and field performance, regardless of lift date (Tab. V). In contrast, the growth chamber RGP results for the February lift date were significantly correlated with June ( 0.88 both plots) and November (0.90 Enguera, 0.83 La Hunde) seedling survival (Tab. V).

The data for RGP, morphological quality and nutrient levels were used to develop models to predict field performance (Tab. VI). In all the cases, $R^{2}$ values were over 0.77 and the standard error was acceptable. In these models, only the RGP from the February growth chamber, the $K$ concentration, and the sturdiness index $(\mathrm{H} / \mathrm{D})$, were useful predictors of field performance.

\section{DISCUSSION}

From this work it can be seen that the RGP of Aleppo pine seedlings was strongly affected by test date, test conditions and seedling stocklot. The short period of the growth chamber test was the most likely explanation for its lower RGP values. Low temperatures in the greenhouse may have caused low RGP values in February but RGP was also lower in the growth chamber at that time $[7,16]$.

Seedling physiological status (dormancy and cold hardiness) is another important source of variation in the RGP test, which is influenced by shoot dormancy and carbon sink strength [24, 25, 33]. Ritchie and Dunlap [24] described a root growth pattern for different species, in which values increased from autumn to the end of winter and then declined before the bud-break. In Aleppo pine, Pardos et al. [16] reported lift date differences in the growth chamber RGP, with a peak in December (between 7 to 12 new roots longer than one $\mathrm{cm}$ ) and very low values in November and January for seedlings maintained in mild and cold temperature regimes. Conversely, our growth chamber RGP mean values in that variable for November and February showed a higher average of new roots (40-50 new roots). Their provenance, test performance conditions or the manner of quantifying the new root growth could be the cause of these discrepancies. Previous studies [19,33] indicate that Aleppo pine has low levels of shoot dormancy throughout the hardening season and is capable of sustaining relatively high photosynthetic rates and, hence, a capacity to grow. This quiescence or lack of true dormancy may be the cause of the inconsistency in the RGP values and their seasonal changes $[7,33]$.

Differences in the RGP are to be expected due to the testing of stock grown in different nurseries and, therefore, under 
Table VI. Significant ( $p$-value < 0.05) regression models fitted for seedling field performance in both sites (Enguera and La Hunde) and RGP or quality attributes.

\begin{tabular}{|c|c|c|c|c|c|c|}
\hline Variable dependent & Independent variables $\left(b_{i}\right)$ & $b_{0}$ & $R^{2}$ & S.E. & $\mathrm{F}$ & $p$-value \\
\hline \multicolumn{7}{|l|}{ Enguera } \\
\hline June survival & RGP Feb-Growth chamber $\left(b_{i}=11.112\right)$ & 0.239 & 0.777 & 0.171 & 13.93 & 0.020 \\
\hline November survival & $\begin{array}{l}\text { RGP Feb-Growth chamber }\left(b_{i}=3.584\right) \text {, } \\
\text { K needle concentration }\left(b_{i}=0.581\right)\end{array}$ & -0.331 & 0.972 & 0.022 & 87.75 & 0.002 \\
\hline \multicolumn{7}{|l|}{ La Hunde } \\
\hline June survival & $\begin{array}{l}\text { RGP Feb-Growth chamber }\left(b_{i}=8.670\right) \text {, } \\
\text { Sturdiness index H/D }\left(b_{i}=-0.097\right)\end{array}$ & 0.969 & 0.935 & 0.043 & 37.14 & 0.008 \\
\hline November survival & $\begin{array}{l}\text { RGP Feb-Growth chamber }\left(b_{i}=13.83\right) \text {, } \\
\text { Sturdiness index H/D }\left(b_{i}=-0.176\right)\end{array}$ & 1.048 & 0.920 & 0.074 & 29.79 & 0.010 \\
\hline
\end{tabular}

different cultural regimes [30]. In the present study, the particular performance of some stocklots with a high $N$ concentration in the February growth chamber test played an important role in the overall results. Outside temperatures in late January 2005 were abnormally low in the region, reaching below $-5{ }^{\circ} \mathrm{C}$. Although Aleppo pine seedlings can be completely resistant to such low temperatures, excessive nitrogen concentrations in plant tissues can prolong the vegetative stage and thus increase the probability of cold injury $[8,10]$. Seedling stocklots with a higher nutrient concentration kept outside just before the growth chamber test took place could have been at this stage during this period, thus being affected by cold injury to some extent either in shoots or roots. Actually, the needle nutrient decrease (especially $\mathrm{N}$ ) found between October and January (Tab. II) may be the result of a retranslocation to the root system sink [12]. This organ has the highest nutrient demand at that time, but is also less cold-tolerant than shoots $[3,13,20]$. This factor might explain the significant relationship found between the RGP and the field results (February and Growth Chamber). Moreover, this result underlines the need to perform the test as closely as possible to the planting date [24]. The value of the RGP as an indicator of plant vigour is probably its main strength [30]. In the present study, morphological and physiological attributes were of no use for detecting the loss of vigour experienced in some of the stocklots used $(\mathrm{Fa})$. These results could explain the scarcity of correlations obtained between them and the RGP values, as observed in other works $[15,27]$. However, some of the correlations obtained for root attributes (e.g. root average diameter, root length to tip ratio and pre-existing white root length) indicate their usefulness as a quick indicative of RGP expression and deserve additional and more detailed research.

Field performance (survival and growth) in both locations were in the expected range under these environmental conditions [1]. Although all the stocklots tested were of the same stock type and provenance, the different growing regimes employed affected seedling quality. This was reflected in the field performance differences. The lack of accepted or standard growing regime protocols and site-specific quality standards for Aleppo pine may contribute to this problem. However, these standards are not easy to establish since the relationships between field performance and stock qual- ity attributes may change during the planting season [16]. For instance, in Aleppo pine, the $\mathrm{N}$ concentration either in shoots [14] or roots [28] has been positively related to survival and growth [19]. In this study, these relationships were absent despite the wide range of $N$ concentrations between the six stocklots tested and the differences in their field performance. Some of these works also reported positive relationships between morphological attributes and performance, which in our case have been, in general, negative. In contrast, the RGP is a stock vigour measurement which has shown previous relationships with field performance in Aleppo pine $[16,34]$ in accordance with our results, where RGP was more related to survival than any other seedling attributes at both sites. In other studies, the absence of relationships could be due to planting them under very favourable conditions or to uncontrolled experiment factors [5].

The RGP actually has a valid predictive ability for this species although it is sensitive to the test conditions. In this sense, a shorter and more intensive test performed in a growth chamber just before planting may be more reliable. The onemonth long test performed under relatively favourable environmental conditions might allow seedlings from a poor stocklot to recover from handling or other damage, resulting in good root growth, a result which is unlikely to occur under harsh field conditions.

\section{CONCLUSIONS}

The RGP test should be conducted in growth chambers due to root growth susceptibility to low temperatures and to be able to complete the test in a short period of time (10 days). The proportion of the variation in survival explained by the test is large enough for decision purposes. In this work, the RGP test has been studied for different quality sites, which could represent ecological extremes found in Mediterranean areas. However, RGP scoring should not be based on only a one year analysis, because of its variation from year to year. In addition, the need to perform the RGP close to the planting date means carrying out at least two or three assays during the OctoberMarch planting season, depending on the factors that affect the stock in the interim until planting. These characteristics would 
probably not fulfill the criteria of an ideal test [35] and would restrict its employment by many potential users (cost, nursery implementation, etc.).

Acknowledgements: This study is incorporated in the project "Improvement of forest plantation establishment in the province of $\mathrm{Va}$ lencia through the definition of seedling quality standards" signed by the Universidad Politécnica of Valencia and the Valencia Regional Government (Generalitat Valenciana).

\section{REFERENCES}

[1] Alloza J.A., Análisis de repoblaciones forestales en la Comunidad Valenciana. Desarrollo de criterios y procedimientos de evaluación, $\mathrm{Ph} . \mathrm{D}$. thesis. Univ. Politécnica Valencia, Valencia, 2003.

[2] AOAC, Official methods of analysis. Association of Official Analytical Chemists, 17th ed, Washington, DC, 2000.

[3] Bigrass F.J., Dumais D., Root-freezing damage in the containerized nursery: impacts on plantation sites - A review, New For. 30 (2005) 167-184.

[4] Burdett A.N., New methods for measuring root growth capacity: their value in assessing lodgepole pine stock quality, Can. J. For. Res. 9 (1979) 63-67.

[5] Burdett A.N., Understanding root growth capacity: theoretical considerations in assessing planting stock quality by means of root growth test, Can. J. For. Res. 17 (1987) 768-775.

[6] Cortina J., Navarro R.M., del Campo A., Evaluación del éxito de la reintroducción de especies leñosas en ambientes Mediterráneos, in: Cortina J., Navarro R. (Eds.), Calidad de planta forestal para la restauración en ambientes Mediterráneos, Estado actual de conocimientos, O.A.P.N. Ministerio Medio Ambiante, Madrid, 2006, pp. 11-29.

[7] Fernández M., Royo A., Gil L., Pardos J.A., Effects of temperature on growth and stress hardening development of phytotron-grown seedlings of Aleppo pine (Pinus halepensis Mill.), Ann. For. Sci. 60 ( 2003) 277-284.

[8] Fløistad I.S., Kohmann K., Influence of nutrient supply on spring frost hardiness and time of bud break in Norway spruce (Picea abies (L.) Karst.) seedlings, New For. 27 (2004) 1-11.

[9] Landis T.D., Skakel S.G., Root growth potential as an indicator of outplanting performance: problems and perspectives, in: Landis T.D. (Coord.), Proc. of the 1988 combined meeting Western forest nursery associations, USDA Forest Service, GTR RM-167, Vernon, BC, Canada, 1988, pp. 106-110.

[10] Landis T.D., Tinus R.W., McDonald S.E., Barnett J.P., Seedling nutrition and irrigation, Vol. 4, The Container Tree Nursery Manual, Agric. Handbk. 674, USDA, Forest Service, Washington DC, 1989.

[11] Levy P.E., McKay H.M., Assessing seedling vitality tests using sensitivity analysis of a process-based growth model, For. Ecol. Manage. 183 (2003) 77-93.

[12] McAlister J.A., Timmer V.R., Nutrient enrichment of white spruce seedlings during nursery culture and initial plantation establishment, Tree Physiol. 18 (1998) 195-202.

[13] McKay H.M., A review of effect of stresses between lifting and planting on nursery stock quality and performance, New For. 13 (1997) 369-399.

[14] Oliet J., Planelles R., Lopez M., Artero F., Efecto de la fertilización en vivero sobre la supervivencia en plantación de Pinus halepensis, Cuad. Soc. Esp. Cien. For. 4 (1997) 69-79.

[15] Oliet J., Planelles R., Artero F., Martínez Montes E., Alvarez Linarejos L., Alejano R., Lopez Arias M., El potencial de crecimiento radical en planta de vivero de Pinus halepensis Mill. Influencia de la fertilización, Invest. Agrar.: Sist. Recur. For. 12 (2003) 51-60.
[16] Pardos M., Royo A., Gil L., Pardos J., Effect of nursery location and outplanting date on field performance of Pinus halepensis and Quercus ilex seedlings, Forestry 76 (2003) 67-81.

[17] Pausas J.G., Bladé C., Valdecantos A., et al., Pines and oaks in the restoration of Mediterranean landscapes of Spain: New perspectives for an old practice - a review, Plant Ecol. 171 (2004) 209-220.

[18] Pearcy R.W., Ehleringer J.R., Mooney H.A., Rundel P.W. (Eds.) Plant physiological ecology: field methods and instrumentation, Chapman and Hall, London, 1989.

[19] Puertolas J., Gil L., Pardos J.A., Effects of nutritional status and seedling size on field performance of Pinus halepensis planted on former arable land in the Mediterranean basin, Forestry 76 (2003) $159-168$.

[20] Puertolas J., Gil L., Pardos J.A., Effects of nitrogen fertilization and temperature on frost hardiness of Aleppo pine (Pinus halepensis Mill.) seedlings assessed by chlorophyll fluorescence, Forestry 78 (2005) 501-511.

[21] Puttonen P., Criteria for using seedling performance potential tests, New For. 3 (1989) 67-87.

[22] Quinn G.P., Keough M.J., Experimental Design and Data Analysis for Biologists, University Press, Cambridge, 2002.

[23] Ritchie G.A., Assessing seedling quality, in: Duryea M.L., Landis T.D. (Eds.), Forest nursery manual: production of bareroot seedlings, The Hague, Martinus Nijhoff/Dr. W. Junk publishers, for Forest research laboratory, OSU, Corvallis, OR, 1984, pp. 243-259.

[24] Ritchie G.A., Dunlap J.R., Root growth potential: its development and expression in forest tree seedlings, N.Z. J. For. Sci. 10 (1980) 218-248.

[25] Ritchie G.A., Tanaka Y., Root growth potential and the target seedling, in: Rose et al. (Eds.), Target seedling symposium, GTR: RM-200, USDA Forest Service, 1990, pp. 37-51.

[26] Rose R., Rose C.L., Omi S.K., Forry K.R., Durall D.M., Bigg W.L., Starch determination by perchloric acid vs enzymes: evaluating the accuracy and precision of six colorimetric methods, J. Agric. Food Chem. 39 (1991) 2-11.

[27] Royo A., Fernández M., Gil L., González E., Puelles A., Ruano R., Pardos J., La calidad de la planta de vivero de Pinus halepensis destinada a repoblación forestal. Tres años resultados en Comunidad Valenciana, Montes 50 (1997) 29-39.

[28] Royo A., Gil L., Pardos J., Effect of water stress conditioning on morphology, physiology and field performance of Pinus halepensis Mill. seedlings, New For. 21(2001) 127-140.

[29] Sampson P.H., Templeton C.W.G., Colombo S.J., An overview of Ontario's stock quality assessment programme, New For. 13 (1997) 461-479.

[30] Simpson D.G., Ritchie G.A., Does RGP predict field performance? A debate, New For. 13(1997) 253-277.

[31] SPSS Inc., SPSS for Windows, release 12.0, SPSS. Inc., Chicago, 2003.

[32] Steel R.G.D., Torrie J.H., Principles and procedures of statistics. A biometrial approach, 2nd ed., McGraw Hill, 1988.

[33] Tinus R.W., Burr K., Atzmon N., Riov J., Relationship between carbohydrate concentration and RGP in coniferous seedlings from three climates during cold hardening and dehardening, Tree Physiol. 20 (2000) 1097-1104.

[34] Vallas J., Villar-Salvador P., Peñuelas J., Herrero N., Domínguez S., Nicolas J., Efecto del aviveramiento prolongado sin riego en la calidad funcional de brinzales de Pinus halepensis Mill y desarrollo en campo, Montes 58 (1999) 51-58.

[35] Zaerr J.B., The role of biochemical measurements in evaluating vigour, in: Duryea M.L. (Ed.), Evaluating seedling quality: principles, procedures and predictive abilities of major test. Forest Research Lab. OSU, 1985, pp. 137-141. 